\title{
Máthé Andrea
}

\section{CSAK SZÍNEK}

\begin{abstract}
Absztrakt
Az írás Krajcsovics Éva festőművész legutóbbi festményeit mutatja be, amelyeknek egyik lényeges jellemzője az a fordulat, amely 2019. évi összefoglaló jellegű albumának megjelenése óta figyelhető meg. A minimalista expresszív művészetben további letisztulás, a színek még további árnyalódása és koncentráltabb megjelenítése került előtérbe a formák szinte teljes elhagyásával, vagy csak éppen látható utalásszerűségével. Ugyanakkor kísérleti jelleggel néhány képen teljesen új festészeti érdeklődést mutatva emberi figura körvonalai is feltűnnek. Ez az alig fél éve kezdődött folyamat egy megőrizve megújulásként is értelmezhető, amelyet a korábbi festői attitűd intenzivitása és az újabb festészeti megoldások keresése egyaránt jellemez.
\end{abstract}

\begin{abstract}
This article is about Éva Krajcsovics Hungarian painter latest paintings, which can be characterized by an essential turn after having published her works' summary book (album) in 2019. In her minimalist expressive art further clarification even more nuances of colour and more concentrated representation came to the foreground with almost complete abandonment of forms or just visible allusiveness. At the same time, as a kind of experiment, the outlines of the human figure on her some paintings also appear which indicates a new direction in her art. This artistic process, which began barely half a year ago, can also be interpreted as a preserved renewal characterized by both the intensity of the earlier painter attitude and the search for newer painting solutions.
\end{abstract}

2020 tavaszán jelent meg Krajcsovics Éva festöművész addigi életművét összefoglaló képzőművészeti albuma. A festményeiből válogatott reprodukciók mellett néhány, a képekhez kapcsolódó szöveg is olvasható, Tolnai Ottó író, Vojnich Erzsébet

1 Krajcsovics Éva szóbeli közlése. (2020.XI.13.) festőművész írásai és festőnaplójából Krajcsovics Éva is közöl részleteket, egy írás pedig kísérletet tesz a festői életút összefoglalására, strukturált megjelenítésére, kiemelve fontosabb szakaszait, csomópontjait, követve változásainak festményekben látható nyomait. Ez a mintegy negyven év alkotói periódus áttekintését jelenti a rajztól a festményig vezető utat, a festészeti irány tudatosulását-tudatosítását, a belső világ, a lélek vezette út egyre inkább szándékon alapuló követését. Az eddigi életmű egységesen összefonódó, egymásra épülő alkotásai azonban mutatják az élet-váltások és -változások nyomait a festményeken, bár kevés, és alig észrevehető téma- és szín-elmozdulásokban. A könyv nem lezárás volt, hanem áttekintés, összefoglalás és egy újabb út kialakításának lehetősége, amely láthatóan meg is valósul. Az alkotói háttér, az indíttatás, az alkotói magatartás és festészeti keresés intenzitása változatlan maradt.

A kötet megjelenése óta is folyamatosan születnek új festmények Krajcsovics Éva műtermében, és ha lehet még elvenni, minden feleslegesnek látszótól megszabadítani festői nyelvét színekben és a valóság tárgyainak absztrakciójában, akkor az utóbbi időben ez a festői periódus valósul meg, vagy, ahogy saját maga mondja: „Most a semmit festem”. Persze kérdés, hogyan ábrázolható az, ami kívülről, külső látással nem látható; ezzel már a középkori misztikusok is találkoztak, mégis megkíséreltek szavakat vagy képeket találni a kimondhatatlanra, kimondani a szóval nem leírhatót, képekké formálni a látomásokat. Vagy egy másik megközelítés a semmi kifejezésének kísérletére a negatív teológia, amely mind az ürességre, mind a semmire is utal, amikor azt állítja, hogy bármit is jelentünk ki Istenről, az nem az, és a megragadhatatlanba, a semmi ürességébe ütközünk.

A semmi az intuíció vagy az ú.n. hatodik (vagy többedik?) érzék segítségével érzékelhető valóságrész, amelynek anyagi megjelenése nincs, ezért nem lehet megjeleníteni, csak az azt érzékelő létállapotot lehet valamilyen módon anyagivá, anyag által megjelenítetté tenni: Krajcsovics Éva legutóbb készült képei ezt kísérlik meg festészete már kialakított eszközeinek, gesztusainak alkalmazásával, 
de egyben megújításával is. Mint hangkép vagy zenemű kottája, amely akkor is tovább emlékeztet a zengésre, amikor már nincs meg az élő hang forrása, a semmi érzékeléséből születő festészet különböző színei is előhívják az emlékezet és a szándék eredetét. Ebben a legutóbbi, nemrég kezdődött újabb periódusban nem Richard Wagner Tristanja zenéjének hangjai szólnak a háttérben, hanem Mozart és Vivaldi muzsikája erősíti, modulálja az inspirációt a festéshez. Megjelenik a fehér a fehéren, a háttérszínből alig elválasztható négyzetes felületek, csíkok, vonalak rejtett formái, a sárgák, a szürkék, kékek együttese, a vörösök a rózsaszínek mellett és együtt - mindezt visszafogott eleganciával, csendre hívó ragyogással.

Amiként a különböző rejtett lélekrétegek a semmi csendjében felnyílnak és megnyílnak a felismerés számára, hasonlóan a takart, fedett festékrétegek legfelszínére kerülő szín is kinyílik, megmutatkozik szemlélődésre invitálva, megfejtésre várva. A látható festékrétegek mögött sok réteget szükséges megfesteni, hogy a legfelső réteg színe valóban a festő elképzelésével egyezzen, vagy legalábbis megközelítse, hiszen az érzésen, belső látáson alapuló vágyott elérésére való törekvés nem mulandó. De éppen a vágyott akarásának köréből szükséges kilépni, hogy az adott szín a maga tökéletességében mutatkozhasson meg. A kontemplatív és a meditatív út visz közelebb vagy vihet el az üresség érzékeléséhez, ez magának a művészi alkotásfolyamatnak is útja, amely néhány festményen például sivatagi tájra emlékeztető színösszhangot hoz létre a különféle sárgák és fehérek egymásra hatásaként. Vagy az Egy nap címü festmény vörösei és csak éppen jelzett vonalai, amelyek a bezártság és szabadság egymásnak feszülését mutatják a címnek ellentmondó átlagosság megcáfolásával. Az ennek nyomán és ebben a lét- és tudatállapotban születő festmények periódusa jelenik meg Krajcsovics Éva művészetében az utóbbi hónapokban.

Elmozdulások történtek az alkotói inspirációban is. Morandi és C. D. Friedrich mellett most előtérbe került számára Van Gogh és Agnes Martin festészete. Képeik, alkotói munkájuk, ars poeticáik inspiráló erővel hatnak rá gondolati, képzeleti síkon is: „Többet festek fejben, mint kézzel” - állítja játékosan, de ebben a metaforában megnyílik festészetének igazsága is, amely egyben az élethez és a léthez való viszonyának változásával párhuzamos. Eltűnt vagy megszűnt az a konkrét külső tárgy vagy dolog, amely inspirációt és emocionális erőt jelentett a festmények megszületéséhez, az utóbbi időben „nincs olyan tárgy, ami igazán érdekelne, ... mostanában a színek hatnak rám szinte 'örületes' intenzitással" ${ }^{2}$ - mondja.

Ha elolvassuk Agnes Martin 1989-ben írt müvészi önvallomás-esszéjét, amelyet $A$ szépség az élet misztériuma ${ }^{3}$ címmel írt, sok hasonlóságot találunk Krajcsovics Éva művészetről alkotott gondolataival, alkotói hozzáállásával, a festészethez, saját festményeihez való viszonyával és képi világával. Néhány mondat az esszéből, amely felvillantja a szemléletmód közös alapját: „Amikor a művészetre gondolok, a szépségre gondolok. A szépség az élet misztériuma. Nem a szemben, hanem az elmében található. ... A szépségre érzelmekkel válaszolunk. ... Minden műalkotás a szépségről szól; minden pozitív munka őt képviseli és ünnepeli. Minden negatív művészet tiltakozik az életünk szépségének hiánya ellen. ... A kompozíció abszolút rejtély. Ezt az elme diktálja. A művész bizonyos hangokat vagy vonalakat keres, amelyek elfogadhatóak az elme számára, és végül azok megfelelő elrendezését".

Mindezekhez pedig egy teljesen új téma is feltünik Krajcsovics Éva legutóbbi képein: az emberi alak megjelenítése a festményen; eddig csak tárgyakra utalt, most azonban két nagyobb méretű festményen egy-egy a nagy színfelületből egy másik alig megkülönböztethető színfelülettel jelölt emberi alak a bontakozik ki. Azt még a jövő dönti el, vajon folytatódik-e ez a tematika, vagy kivétel marad e két festmény.

Mert valóban: csak a színek maradnak néhány jelzésszerű vízszintes vagy függőleges vonallal, csíkkal, holott általában a figurálisból indulnak a színfelületekké alakuló képek - egy szobasarok, egy ablak, egy margitszigeti virágágyás visszképe, egy pillanatra látott utcakép emléke -, de az újabb és újabb színrétegek eltüntetik a figurát és a színek dinamikája, együttélése válik láthatóvá. Néhány képen a fehér vászon marad meg és képvisel önálló színt, hogy a mellette lévő nagyobb hangsúlyt kaphasson, ahogy például egy fehérekkel megfestett festményen, amelyen hívássá és meghívássá értelmeződik vászonfehéren jelzett ajtó körül a fehérek összjátéka. Ez az, ami szintén nagyon fontos a mű festője számára: hogy a színek kifejező ereje képes legyen megteremteni a kép témáját és tartalmát, értelmezését nézői számára. Vagyis nem öncélú vagy didaktikus

2 Krajcsovics Éva szóbeli közlése. (2020.XI.27.)

3 Agnes Martin: Beauty is the Mystery of Life - online: https://www.artbook.com/blog-excerpt-agnes-martinbeauty-is-the-mystery-of-life.html (2020.XII.02.)

4 Az idézett sorok saját fordításom. 
szín-játékról van szó, hanem a színek értelemalkotó erejének kialakításáról, megmutatásáról.

A folyamatosan készülő Levelek Van Goghozsorozat festményei a visszafogott színek változatosságával mutatkoznak a 40x50 cm-es méretben készített egy-egy teljes vászonfelületet elfoglaló, Van Gogh festményeinek egy-egy sajátos színére vagy festményeinek hangulatára utaló felülettel. A színrétegek egymásra hatásaként a vászonfelülettől a legutolsó rétegig kialakított szín mind tudatos, mind intuitív alkotómunka eredménye spontán hatása mellett fegyelmezettségből eredő erőt is hordoz.

Martin Heidegger XX. századi filozófus teszi fel a kérdést: miért van a valami, mint inkább a semmi? E kérdést követő lehetséges kérdés: miért, hogy a valamit érzékeljük inkább, mint a semmit? A kettéválasztást azonban felülírja a valami és a semmi együttes léte, egybefonódása: mert a valami és a semmi együtt-létben van, szétválaszthatatlanul. Hiszen ki tudná, ki tudja önmagát az üresség betöltéseként érzékelni? Nem könnyű, hiszen gondolkodásmódunk általában két pólusra állítódott be az idők folyamán. Krajcsovics Éva önmaguk erősségében - önmaguk mértékében, arányaiban, igazolásra nem szoruló létükben - megálló festményei láthatóvá, vagy még inkább érzékelhetővé teszik a valami és a semmi egymást feltételező létét. Képein és képei körül pedig az ürességre utaló belső tágasság jelenléte erősödik fel, amelyet a minden fölösleges visszavonása teremt meg és tesz lehetővé. Ahogy alkotójuk belső világában oldódnak fel a rétegek a csend felé, hasonlóan festményei úgy tüntetik el a felesleges rétegeket, hogy a legtisztábbá váljon a látható, hogy megmutatkozhasson a kép felszínének tágassága és mélysége. 